\title{
FAMILY RELATIONSHIPS IN THE CONTEXT OF GENDER-BASED VIOLENCE ${ }^{1}$
}

\author{
Vanda Palmarella Rodrigues², Adriana Diniz Rodrigues, ${ }^{3}$ Margaret Olinda de Souza Carvalho e Lira ${ }^{4}$, Telmara \\ Menezes Couto ${ }^{5}$, Normélia Maria Freire Diniz ${ }^{6}$
}

\footnotetext{
${ }^{1}$ Text from the dissertation - Social representation of the family on gender-based violence, presented at the Programa de PósGraduação da Escola de Enfermagem, Universidade Federal da Bahia (UFBA), in 2015.

${ }^{2}$ Ph.D. in Nursing. Professor, Health Department, Universidade Estadual do Sudoeste da Bahia. Jequié, Bahia, Brazil. E-mail: vprodrigues@uesb.edu.br

${ }^{3}$ Ph.D. in Nursing. Professor, Nursing Graduation Course Faculdade Regional da Bahia. Alagoinhas, Bahia, Brazil. E-mail: adrianadinizr@gmail.com

${ }^{4}$ Ph.D. in Nursing. Professor, Universidade do Vale do São Francisco. Petrolina, Pernambuco, Brazil. E-mail: olindalira@gmail.com

${ }^{5}$ Ph.D. in Nursing. Professor, Escola de Enfermagem UFBA. Salvador, Bahia, Brazil. E-mail: telmaracouto@gmail.com

${ }^{6}$ Ph.D. in Nursing. Professor, Escola de Enfermagem UFBA. Salvador, Bahia, Brazil. E-mail: normeliadiniz@gmail.com
}

\begin{abstract}
This study aimed at analysing social representation of family relationships in the context of gender-based violence. This qualitative research was based on the Theory of Social Representations and it was conducted with 19 family members of women in the situation of gender-based violence, registered in Family Health Strategy units of Jequié, Bahia. Data was collected through a semi-structured interview between April and September 2014 and data organization was done according to the content analysis technique. The family members' social representations showed gender-based violence as a crime and the need towards actions to minimize its occurrence. They also indicated that gender-based violence results in illness of family members and as it is restricted to the private area of the house, it contributes towards its silence. Proper training of health, education and welfare services of the anti-violence network is urgent, observing public policies dealing with gender-based violence.
\end{abstract}

DESCRIPTORS: Violence against women. Family health. Gender and health. Nursing.

\section{RELAÇÕES FAMILIARES NO CONTEXTO DA VIOLÊNCIA DE GÊNERO}

RESUMO: Estudo que objetivou analisar as representações sociais das relações familiares no contexto da violência de gênero. A presente pesquisa, qualitativa, baseou-se na Teoria das Representações Sociais e foi realizada com 19 familiares de mulheres em situação de violência de gênero, cadastrados em unidades da Estratégia Saúde da Família de Jequié, Bahia. A coleta ocorreu por meio da entrevista semiestruturada, entre abril e setembro de 2014, e a organização dos dados seguiu a técnica da análise de conteúdo. As representações sociais dos familiares mostraram a violência de gênero como crime e pontuaram a necessidade de ações que minimizem a sua ocorrência. Elas também assinalaram que a violência de gênero gera adoecimento dos familiares e restringe-se ao espaço privado da casa, favorecendo o silêncio. Urge a adequação da formação em saúde e educação e dos serviços assistenciais da rede de violência, observando as políticas públicas no enfrentamento da violência de gênero.

DESCRITORES: Violência contra a mulher. Saúde da família. Gênero e saúde. Enfermagem.

\section{RELACIONES FAMILIARES EN EL CONTEXTO DE LA VIOLENCIA DE GÉNERO}

\begin{abstract}
RESUMEN: el artículo objetiva analizar las representaciones sociales en las relaciones familiares en el contexto de la violencia de género. Esta investigación cualitativa, se basó en la Teoría de las Representaciones Sociales realizada con 19 familiares de mujeres en situación de violencia de género, inscritos en unidades de la Estrategia de Salud de la Familia de Jequié, Bahia. La colecta ocurrió se llevó a cabo a través entrevista semiestructurada entre abril y setiembre de 2014 y la organización de los datos siguió la técnica de análisis de contenido. Las representaciones sociales de los familiares mostraron la violencia de género como crimen y anotó la necesidad de acciones que minimicen su ocurrencia. También señalaron que la violencia de género genera padecimiento de los familiares y es restringida al espacio privado de la casa, favoreciendo el silencio. Urge la adecuación de la formación en salud y educación y de los servicios asistenciales de la red de violencia, observando las políticas públicas en el enfrentamiento de la violencia de género.
\end{abstract}

DESCRIPTORES: Violencia contra la mujer. Salud de la familia. Género y salud. Enfermería. 


\section{INTRODUCTION}

Gender-based violence occurs within relationships of power between women and men, configured by women's subalternity and by asymmetries that determine social norms and rules regarding the behaviour of both women and men. ${ }^{1}$

The global prevalence of physical and/or sexual violence perpetrated by an intimate partner was $30 \%$, considering the estimate of 79 countries. Brazil registered the average of 4.8 femicides by 100 thousand women, ranking the $5^{\text {th }}$ worldwide position amongst a group of 83 countries. Through the Sistema de Informação de Agravos de Notificação (SINAN), it was also registered that 223,796 victims of domestic, sexual and/or other violence were reported in 2014, of which two in every three of these victims of violence $(147,691)$ were women in need of medical assistance. For women aging 18 to 59 years old, the main offender was the partner or the ex-partner..$^{2-3}$

Gender-based violence in the loving relationship reveals the man's control over the body, sexuality and mind of the woman, showing at the same time, in one hand, the difference established between men and women within family and society, and, on the other hand, the maintenance of power and domination disseminated in the patriarchal order. ${ }^{1}$

The patriarchal culture establishes a hierarchy that invades all areas of society: it holds a material basis, it embodies and represents a powerful structure, based upon both the macho/ sexist ideology and violence. ${ }^{4}$ This relationship may also be seen in family relationships, reaffirming gender-based violence.

In this respect, the support by religious, family, friends and Non-Governmental Organizations represents the social support network for women under violent situations, being important elements to confront marital violence, as they provide emotional, spiritual, and material support, and information. ${ }^{5}$

By searching national and international database using the key word violence against women, we noted that, in spite of increased theoretical production about gender-based violence, the majority of studies on social representations focused on testimonials by women, men or professional from the violence network, focusing on women's psycho-social consequences.

A knowledge gap was identified, which prompted us to search for the understanding of family relationships in the context of gender-based violence, based upon the Social Representation
Theory (SRT), taking into consideration that social representation result from information, attitudes, values, believes and opinions drawn from human interaction, between two people or amongst a group of people over an object or situation, from a subjective and social view of reality, influencing and directing behaviours, practices and decisions which are part of daily life. ${ }^{6}$

This research aimed at analysing the social representation of family relationships in the context of gender-based violence.

\section{METHOD}

This is a qualitative approach research, performed with 19 family members of women under gender-based violence, registered at the Health Family Units (USF), including six mothers, five sisters, one daughter, one son, one mother-in-law, three cousins and two sisters-in-law.

The study was performed in 10 USF, four of which had single teams and six had double teams; only one of these USF undertook the interview with registered family members in both teams, totalling 11 teams of Health Family Strategies (ESF) in the municipality of Jequié, in Bahia's country side. Regarding the inclusion criteria we considered family members of women in gender-based violence as the family members of blood relationship or not, living in the same house of the woman or in their own house, registered at the USFs selected for the study, over 18 years-old, able to communicate verbally; those with health issues that would not allow participation, like being in hospital, for instance, were excluded.

Data was collected through a semi-structured recorded interview, which took place from April to September 2014. Interviews were 40 minutes long in average. Eleven interviews took place at USFs, and eight at home.

Data collection took place after the approval of the research project by the Research Ethics Committee of the Nursing School at the Universidade Federal da Bahia, under opinion No. 456.776/2013, CAEE 23641513.8.0000.5531, where ethical precepts were established under Resolution No. 466, dated December 12, 2012, with the preliminary request by an informed consent form signed by the participants.

Regarding data organization, content of analysis method was used - theme modality - with the aim of discovering a nucleus that made sense and that allowed for meaningful communication towards the proposed objectives, following three stages, starting 
with a pre-analysis, which consisted of fluctuating reading of empirical material related to the interviews. Several readings of the interview's content allowed for a codification of data from clipped texts for the identification of units of registry. Thereafter, data was classified and combined under themes, categories and sub-categories. ${ }^{7}$

During the interpretation and discussion phase, critical relationships were established between the explicit or implicit testimonials of staff, and the scientific context, where we based the analytical gender category as well as social representations.

In order to ensure anonymity, we used the letter E, meaning interviewed (entrevistado), followed by the Arabian algorism corresponding to the ascending order of the interview and the family relationship with the woman in the situation of violence. For example, (E1, sister) and so forth.

\section{RESULTS AND DISCUSSION}

Interviewed people aged between 20 and 70 years old, of which only two were males. Regarding race, 15 were black and four were whites, according to the classification from the Instituto Brasileiro de Geografia e Estatística (IBGE). As to schooling, four were illiterate, four had concluded primary school, seven had concluded high school and four had higher education.

As to marital status, 11 were married, two were single, three were widows and three were under common-law relationships. Regarding family income, one had no fixed income, five earned up to a minimum wage amount, nine earned between one and three minimum wages amount and four earned between three to five minimum wages amount; only five earned bolsa-família. Regarding occupation, five participants entitled themselves as housewives, three were retired, one was a pensioner, seven were health community agents (ACS), amongst other professions.

Gender-based violence within family relationships was discussed from the following categories: The expression of gender-based violence within family relationships; Implications of violence in the family's health; Children taking part in aggressive acts; Feelings of family members.

\section{The expression of gender-based violence within family relationships}

Family members of women in the situation of gender-based violence stated living with violence in family relationships' daily life.
I thought of my dad coming home on the weekend, because he would come home eager to hit, shutting the door so that she [mother] could not get in, wanting to hit, breaking furniture [...] I do not accept this, regarding a man beating up a woman, I thought this was terrible, I didn't know how to deal with this [...] I was completely cold, I could not be the same daughter [...] (E3, daughter).

In the relationship between men and women, gender inequality is not given, but built. ${ }^{4}$ Such building was rather evident in the family's interaction between the couple living in the context of violence and their family members.

Interviewee 11 attested not talking to her sister because she was threatened, by her (the sister) and her partner, given she reported at the Tutelary Council.

[...] She [sister] was missing since Friday afternoon; I called the Tutelary Council because of the children, the Tutelary Council called the police, [she was] at a drug's house, [they] brought her back [...]. I withdrew myself from her, because since this occasion when I called the Tutelary Council, she threatened me, along with him [the aggressor], they threatened me, we were really upset, we didn't even talk [...] She threatened me of death [...] (E11, sister).

The report indicated that the sister acted according to the law by reporting abusive behaviour of family members against the children, but even though, she received death threats.

Distancing the aggressor from family relationships was also evidenced in the following speech: [...] I had him as a son [aggressor, son-in-law] [...]. He was raised in my house, there was so much freedom that he used to call me mommy; he took money from me several times, nowadays [...] I don't let him into my house [...] (E19, mother).

Loss of trust hinders family interaction.

Participants also indicated that violence leaves the family on alert for violent instances.

I witnessed, one day she [sister] was coming from a party late at night, I was already asleep, I knew she had gone out, I was already waiting for her to arrive. That - as I am a light sleeper, I heard cries for help. 'Help! Help' That's when I called my husband so that we could go help, he [aggressor] had already beaten her up, her mouth was already badly hurt, she even went to the ER [Emergency Room] [...] She pressed charges [...] against him, she was threatened, not only her but me as well, we were threatened, we felt cornered, then we decided to withdraw [charges] [...] (E1, sister).

He stayed at my mother's house, but those were six months of violence [...]. It was a short period, but rather 
intense [...]. He ended up killing her [...] (E11, sister).

The testimonials show that, although not in the same housing, family members are also involved in the situation of violence, protecting the woman facing changes in her daily life.

Women in situation of violence were supported by family and/or friends, mostly regarding the support needed for the decision of pressing charges against the aggressor and asking for help, despite the prevalence of signs of hardships from usual abdication and uncertainties. ${ }^{8}$

Testimonials also present the family members and the aggressor's routine, and these family members resourced to several supportive actions to implement ties and promote interaction, as per the excerpts of the interviews below:

[...] he comes to my house [aggressor, son-inlaw], I treat him well, he eats and all, because if I say anything against him [...] the daughter might get upset [...] (E9, mother).

[...] with my brother and sister-in-law I see a situation that I need to get even closer [...]. I have a credit card [...]. I see this as a way to interact with him, as he is also introspective, I try to establish ties [...] (E15, sister-in-law).

SRT is directed towards the construction and transformation of social knowledge, produced in different settings of the routine and, through it, a wide range of knowledge deeply linked to the world of life and the experience of the community, which demarcates its referentials regarding thought, action and relationship. ${ }^{9}$

Therefore, we can apprehend the social representation of family members on gender-based violence either as crime - when they go press charges with the woman - or means of help - in the sense of minimizing such occurrences.

Social representations transform objects, people and events into conventions, categorizing and defining them as a model to be accepted and shared by a group of people, where language and culture might influence them. Furthermore, representations are prescriptive, imposing themselves over people with irresistible power, resulting from an existing structure before thought and tradition, which in turn establishes what must be thought. ${ }^{6}$

We can, therefore, deduce that these relative's representations have a tendency to reproduce cultural issues in the dynamics of violence, influenced by communication means, traversing generations and perpetuating itself up to the current context.

A study based on SRT showed family support as an essential element to reinforce empowerment of women in the situation of violence. ${ }^{5}$

Support provided by the family network within the context of gender-based violence has also been highlighted in literature, where it is shown that, despite isolation as a resort, some of these women feel as part of a socio-human network, allowing them to think of alternatives such as staying by the aggressor or cutting ties with the partner, especially when they trust mothers and share with them their experiences of violence, ${ }^{10}$ asking for guidance on how to leave this tough situation.

The pathway found by family members to provide support is important, without disregarding the experiences and trying to help. However, it is not enough, as at a certain point the situation of violence becomes unbearable, demanding institutional help from the violence network services. In this sense, the role of public policies is highlighted as to confronting gender-based violence.

\section{Implications of violence in the family's health}

Experiencing gender-based violence results in physical illness and psychological suffering of family members, as per speeches below:

I try do advise about the troubled issues, I get sick, I have already ended up in hospital twice, almost dead, the doctors and the police at the hospital told me to leave this mess, that I should not get involved, otherwise I would die, because it was too much pressure, I am hypertensive [...] (E9, mother).

[...] we left here at midnight countless times to go to their house, to stop their fighting, [...]. It's very tense; there is no peace at all. Then you cannot live well, you do not work properly, you are not a good mother, you are not a good wife, your husband is also not a good husband, because everything influences everything, everything is thrown over the family [...] (E19, mother).

Testimonials show that family members living with gender-based violence get physical and mentally ill: hypertensive crisis and nervous breakdowns are just some of the consequences of this problem, where there is no peace within the family and the social roles of family members are hampered. Another important issue is the bio-psychosocial development of children getting involved with drugs.

In general, a family structure its interaction based upon values deemed important for a common living; these values are passed from generation to generation in the educational process of children as a family legacy. However, when common of values 
do not exist, and people act in different ways, the result is conflictive and stressful interaction of family members. ${ }^{11}$

This conflictive interaction, in its turn, allows for gender-based violence, reaching the life of children, who then live with fear and anger, especially when this situation is not resolved through dialogue.

[...] The children [...] the older would get scared and the younger would rush here to my house. 'Grandma, my dad is fighting again with my mom and I am not going there anymore [...]' (E10, mother-in-law).

They became 'angry boys', throwing tantrums, anything we say, they shout, kick. I will throw a stone, I will kill [...] from witnessing fights in their home, they become angry [...] (E9, mother).

Family members understood that the violent relationship of the parents was harmful for the children; they identified behavioural changes, as children started to fear and feel angry, becoming aggressive and having learning disabilities.

To this day this boy cannot read properly, he is almost the age of my son, who is in the first grade [high school] and he seems to be in the fifth grade [...]. If you give him something to read, he doesn't [...]. The suffering that they have already been through [...] (E6, sister).

[...] The three of them learn little, sometimes you ask them to do something, one is restless, the others are too slow, so everything is related [...] (E19, mother).

By emphasizing that the violence perpetrated by the intimate partner is associated to behavioural problems of their children of school age, the findings of this study correspond to what literature says about the subject: woman experiencing violence by the intimate partner was a sine qua non condition for their children to have three or more behavioural problems, regardless of the social or community support. $^{12}$

One sister emphasised the fact that her three nephews witnessed their mother's death, as per excerpts of the interview below:

[...] he went there with the knife and stuck it up into her neck in front of the children [...]. It was terrible [...]. We had to go in the streets at night looking for these boys [...]. When they were hungry, they would ask for food from door-to-door, they would run away. [...]. I would ask: 'Why do you run away like this?' 'Oh aunt, I don't know, something happens on my mind, we go on walking' [...] a bewilderment, running away from the situation [...] (E11, sister).

This fact can be the cause of psychological trauma and social vulnerability.
The use of drugs, teenage pregnancy and prostitution were also mentioned by family members of this study as results of gender-based violence in the lives of children from these women.

We are family members, we see my sister's children in the same situation [...]. The husband is a drug user, the daughters are on the same path [...] they got involved with drug users, they already have children; one is 17 and the other 18 years old [...] (E5, sister).

The influence of fights, every moment that they were fighting I immediately thought of forgetting about it, I would drug myself [...] that was a new horizon in my life, I tried to forget about things that I was living in prostitution, drugs [...]. It's really a result of the violence at home that will result in the child [...] (E16, son).

Several factors make teenagers vulnerable to behavioural changes and to health problems. Amongst them, individual factors, such as gender, age and psychological characteristics, like low self-esteem, low self-confidence and poor determination; family factors related to a history of mental illness, problems with alcohol and/or drugs, physical psychological and sexual violence, violence between parents, loss due to death, parents separation; sociocultural factors such as poverty, violence at the social context, lack of social support; and biological factors, clearly understood. ${ }^{13}$

Unfavourable conditions throughout childhood and teenage years, including having alcohol and/or drugs at home, besides experiencing poverty and violence, is evidenced by families under degrading situations as well as the fact that having witnessed marital violence have marked the childhood of drug-dependent women. ${ }^{14}$

Setting of a favourable environment towards behaviours such as using drugs is influenced by a series of factors, where family is the most important one. Furthermore, although the use of drugs by parents is directly related to a higher risk of children becoming users, given their behavioural model, it is the permissive attitude that weighs more in the equation. ${ }^{15}$

The potential risks for alcohol use by teenagers, identified in the family context, are related to lack of parental support: liberal parents, conflictive relationship of parents, abuse and gender-based violence, amongst other factor. ${ }^{16}$

Within the violence relationships settings, related to alcohol use and the use of other drugs, the misuse of psychoactive substances must not be assumed as a social and complex phenomena like violence, so that we do not fall again in the positiv- 
ist reduction of single causality, as gender issues are notorious, like oppression, which always fall over women and children, as they, amongst other aspects, ${ }^{17}$ have less power.

The World Health Organization emphasizes that domestic violence results in countless implications in physical and mental health of women and their children, and that health staff have several difficulties in asking women about violence, considering lack of time, training and specific professional competence. $^{18}$

A research showed that confronting gender-based violence by female (and male) ESF staff seemed like it was limited to a discussion about actions by the team, which did not involve women, in view the motivation of a proactive attitude and the citizenship practice. ${ }^{19}$ In this context, it is important to reflect about the complexity of violence, crossing generations and unfoldings related to life and health conditions, demanding a closer look by public policies and the assistential network for both these demands.

\section{Children participating in aggressive acts}

Family members disclosed that children participate in the episodes of violence.

They are four children [...]. Their experience, when there are frictions at home, the girls protected the mother [...]. When the dad was going to hit [...] they would stand in front of her, because [...]. He was drugged, the girls would hit him to [...]. Everyone gets involved [...] (E5, sister).

Before, when I was younger, we would see their sadness, we would cry a lot, but nowadays they are 'grownup', they are big girls. If something happens to the mother, thank God they grew up, they protect the mother now [...] I feel sorry for the children, there is a young one [...] his [the aggressor's] grandson [...]. He was still going to be two! [emphasis], he took the knife, as he doesn't speak properly, he showed the grandfather mumbling 'hum, hum, hum', meaning he would strike the grandfather to protect the mother [...] (E6, sister).

The child still doesn't know what to do [...]. Nowadays, he goes over him, but until five years old he would run out, shouting in the house: 'help grandma, help, help here, help here', that distress (E15, sister-in-law).

Testimonials show that children started taking part in the events of violence, protecting the mother. A study showed the need for emotional support for children of couples that witness gender-based violence, emphasising that children witnessing violence are vulnerable and might have their psy- chosocial health compromised, therefore tending to naturalize and reproduce such behaviour in their social relationships. ${ }^{20}$

We emphasize here the importance of family in socializing members that experience gender-based violence, based on family and sociocultural values learned from network interaction, established between family, culture and society. ${ }^{21}$

\section{Feelings of family members}

Affections are the basis of social representations, as the object urges us to talk about it as a compulsion. It is not just about filling in gaps, to lessen distances between what is known, in one hand, and what is seen, on the other, but reaffirming ties with the group, recognizing family members as participants of that group, as they speak the same language. ${ }^{22}$

In this sense, family members testified that interaction within a violent setting caused sadness and distress, followed by suffering, feelings resulting from feeling helpless.

My mother suffered a lot, because she lived in the house below and she would hear the yelling, furniture being broken, the door being broken, because he would arrive breaking everything [...]. A suffering for who sees and cannot do anything [...] (E11, sister).

I feel helpless, because we want to help but do not know how [...]. We are sad, because it depends on her to leave this problem [...]. My dad also feels very sad with this situation [...] (E5, sister).

The worst thing is that I can't even go there, I just stay in the garden [...]. Unfortunately we can't do anything [...]. I go out in the garden to try to defend her, but my children don't want me to go there [...]. He can harm me [...] (E6, sister).

Family members emphasised the feeling of helplessness when facing gender-based violence. This results from the fear of the aggressor, or from the fact that the woman does not accept any help. By affirming that they could not interfere in the situation of violence, by fear of the aggressor's reaction as well as the consequences such involvement would cause, the sisters stated their helplessness. This shows the power of the man, extended to family members, who thus, tries to limit any chance of empowering the woman.

A study verified that the longer the couple has been living together, the greater are the results of the violence suffered by the woman, transforming the settings of social networks, increasingly restricted 
and reduced, to actors of little support. Social and human network restriction, in its turn, limits the access to the social and institutional network, making it difficult, allowing for the woman to remain in the situation of violence. ${ }^{10}$

Therefore, it is important that ESF teams include family members in prevention and control actions of gender-based violence, taking into consideration that these family members need care in order to support the woman to confront the situation of violence, and that the family is involved and needs to be heard.

This study highlighted that fear was constantly present in the life of the family members living with the woman under a situation of violence, even those who did not live in the same household.

We, the family, are destroyed, the panic, the crying, the fear of listening to death [...] (E13, mother).

My mother's great fear, the neighbours would call. Sometimes it's so strong, the child goes out screaming like crazy [...]. She was always careful with the issue of calling the police, because it's shameful and it is also her image as a mom [...] (E15, sister-in-law).

Testimonials show the fragility and vulnerability of the woman upon gender-based violence. Furthermore, the mother's fear that the neighbours would report the aggressions, upon the reaction of the children experiencing the aggressions, show that some family members seem to contribute that gender-based violence remains hidden inside the households, making it difficult for the woman the decision to confront the situation.

The manner how social representation's contents are determined and organized results from the ideological relationship with the social world, with the institutional norms and with the ideological models that are followed. It lies in the place where individuals occupy or the roles exercised and it defines the social exchange corresponding to a game of determinations linked to a structure and to social relations, so-substantiated by language, allowing for ideas, ties and social identities to be formed. ${ }^{23}$

In the social imagery of some family members, the idea that violence must remain within the private setting still prevails, like the fear of calling the police as an example, thus publicly exposing the situation of violence.

The fear of frequent threats and aggressions, added to the shame of remaining in such relationship, contributes towards the woman's isolation, preventing her to expose the experienced violence. In fear of new aggressions, women go to the point of avoiding relationships considered unwanted by their husbands, taking them, in turn, to a silence that extends itself to the institutions that could provide them some support. ${ }^{10}$

This study showed that women under situations of violence look for support first within her closest social means, where family and friends plays an important role. However, support and help actions to women under situations of violence, although bringing understanding, solidarity, protection and improved economic conditions, sometimes do not match with women's expectations, which go beyond the immediate consequences of violent acts. ${ }^{24}$

Another study determined that woman in a situation of violence practiced by her intimate partner is abandoned by her family; they blame the woman for the violence experienced and do not promote confrontation of the situation, ${ }^{25}$ which in turn results in the woman having to undergo and bear such situation.

Added to this is the fact that ESF staff tends to focus the phenomena in the private setting, without analysing the social health factors pertaining to the life and health conditions of the people involved. ${ }^{26}$

ESF, in tis turn, as a public health policy, through its health staff, needs to recognize that these family members feel helpless having a family member living in a situation of gender-based violence. Therefore, it is essential that violence-confronting policies are effected at ESF.

\section{CONCLUSION}

Social representations of family members on gender-based violence direct the behaviour of these family members in the group where they belong; such representations show that violence is a crime and that family members act in several ways to help minimize violent acts in daily life relationships.

Interaction with violence in the family relationships, in its turn, allowed for participants to get ill. This compromised the psychosocial and behavioural development of children, which led them to get involved with drugs, prostitution and teenage pregnancy.

Given all of this, the feelings shown by family members were sadness, distress, fear and helplessness. This is due the fact that in the majority of times, they cannot interact within the violence setting, trying to minimize or to solve the situation, either by fear of the aggressor or for understanding that leaving this situation relies in the woman alone. 
Gender-based violence, as shown by these social representations, has been restricted to the household, which could be largely linked to cultural issues. This contributes towards the legitimation of gender-based violence in the family relationships context and it seems to have become more difficult for the woman to confront such situation.

We emphasize that, in the gender-based violence context, action must not be restricted to the health sector, where actions developed by the health professionals at the violence network expand their coverage: these representations must envisage equal care for the woman under the situation of violence, including the family as a care unit that interacts in this context.

Furthermore, it is up to the public management to structure the gender-based violence network services in a way that it allows women and family members as effective network that is understood across sectors.

\section{REFERENCES}

1. Bandeira LM. Violência de gênero: a construção de um campo teórico e de investigação. Soc Estado. 2014 Mai-Ago; 29(2):449-69.

2. World Health Organization. Global and regional estimates of violence against women prevalence and health effects of intimate partner violence and non-partner sexual violence. Geneva (SW): World Health Organization; 2013 [cited 2014 Dez 02]. Available from: http://apps.who.int/iris/bitstre am/10665/85239/1/9789241564625_eng.pdf?ua=1

3. Waiselfisz JJ. Mapa da Violência 2015: homicídios de mulheres no Brasil [internet]. Brasília (DF): Organização Pan-Americana da Saúde/Organização Mundial da Saúde; Secretaria Especial de Políticas para as Mulheres; Ministério das Mulheres, da Igualdade Racial e dos Direitos Humanos; Faculdade LatinoAmericana de Ciências Sociais; 2015 [cited 2016 Jun 06]. Available from: http://www.mapadaviolencia. org.br/

4. Saffioti HIB. Gênero, patriarcado, violência. São Paulo (SP): Editora Fundação Perseu Abramo; 2004.

5. Gomes NP, Diniz NMF, Reis LA, Erdmann AL. The social network for confronting conjugal violence: representations of women who experience this health issue. Texto Contexto Enferm [internet]. 2015 [cited 2016 Jan 10]; 24(2):316-24. Available from: http:/ /www. scielo.br/scielo.php?script=sci_arttext\&pid=S010407072015000200316\&lng=en\&nrm=iso\&tlng=en

6. Moscovici S. Representações sociais: investigações em psicologia social. 9a ed. Petrópolis (RJ): Vozes; 2012.

7. Bardin L. Análise de conteúdo. São Paulo (SP): Edições 70; 2011.
8. Oliveira PP, Viegas SMF, Santos WJ, Silveira EAA, Elias SC. Women victims of domestic violence: a phenomenological approach. Texto Contexto Enferm [internet]. 2015 [cited 2016 Jan 10]; 24(1):196-203. Available from: http://www.scielo.br/pdf/tce/ v24n1/pt_0104-0707-tce-24-01-00196.pdf

9. Jovchelovitch S. Os contextos do saber: representações, comunidade e cultura. Petrópolis (RJ): Vozes; 2008.

10. Dutra ML, Prates PL, Nakamura E, Villela WV. A configuração da rede social de mulheres em situação de violência doméstica. Ciênc Saúde Colet. 2013 Mai 18(5):1293-304.

11. Althoff CR. Delineando uma abordagem teórica sobre o processo de conviver em família. In: Elsen I, Marcon SS, Santos MR, organizadores. O viver em família e sua interface com a saúde e a doença. Maringá (PR): EDUEM; 2002.

12. Durand JG, Schraiber LB, França-Junior, Barros C. Repercussão da exposição à violência por parceiro íntimo no comportamento dos filhos. Rev Saúde Pública 2011 Abr; 45(2):355-64.

13. Santos DCM, Jorge MSB, Freitas CHA, Queiroz MVO. Adolescents in psychological distress and mental health policy for children and youth. Acta Paul Enferm. 2011 Nov-Dez; 24(6):845-50.

14. Bittar DB, Nakano AMS. Violência intrafamiliar: análise da história de vida de mães agressoras e toxicodependentes no contexto da família de origem. Texto Contexto Enferm [internet]. 2011 [cited 2016 Jan 10]; 20(1):17-24. Available from: http:/ / www.scielo.br/scielo.php? script $=$ sci $_{-}$ arttext\&pid=S0104-07072011000100002

15. Marangoni SR, Oliveira MLF. Triggering factors for drug abusein women. Texto Contexto Enferm [internet]. 2013 Jul-Set [cited 2016 Jan 10]; 22(3):662-70. Available from: http:/ / www.scielo.br/scielo.php? script=sci_ arttext\&pid=S0104-07072013000300012

16. Rozin L, Zagonel IPS. Risk factors for alcohol dependence in adolescents. Acta Paul Enferm. 2012 Mar-Abr; 25(2):214-8.

17. Fonseca RMGS, Egry EY, Nóbrega CR, Apostólico MR, Oliveira RNG. Recurrence of violence against children in the municipality of Curitiba: a look at gender. Acta Paul Enferm. 2012 Nov-Dez; 25(6):895-901.

18. World Health Organization. Relatório Mundial de Saúde 2008: cuidados de saúde primários - agora mais do que nunca. Geneva (SW): World Health Organization; 2008 [cited 2014 Dez 02]. Available at: http://www.who.int/whr/2008/whr08_pr.pdf

19. Rodrigues VP,MachadoJC,Simões AV, Mendes VMMP, Paiva MS, Diniz, NMF. The practice of family health strategy workers when caring for women in gender violence situations. Texto Contexto Enferm [internet]. 2014 Jul-Set [cited 2016 Jan 10]; 23(3):735-46. Available from: http://www.scielo.br/scielo.php?script=sci arttext\&pid=S0104-07072014000300735

20. Gomes NP, Erdmann AL. Conjugal violence in the 
perspective of "Family Health Strategy" professionals: a public health problem and the need to provide care for the women. Rev Latino-Am Enfermagem. 2014 Jan-Fev; 22(1):4-9.

21. Schenker M. Valores familiares e uso abusivo de drogas. Rio de Janeiro (RJ): Editora Fiocruz; 2008.

22. Arruda A. Meandros da teoria: a dimensão afetiva das representações sociais. In: Almeida AMO, Jodelet D, organizadores. Representações sociais: interdisciplinaridade e diversidade de paradigmas. Brasília (DF): Thesaurus; 2009.

23. Almeida GJ. As representações sociais, o imaginário e a construção social da realidade. In: Santos MFS, Almeida LM, organizadores. Diálogos com a teoria das representações sociais. Recife (PE): Editora Universitária da UFPE; 2005.
24. Santi LN, Nakano AMS, Lettiere A. Percepção de mulheres em situação de violência sobre o suporte e apoio recebido em seu contexto social. Texto Contexto Enferm. 2010 Jul-Set; 19(3):417-24.

25. Silva EB, Padoin SMM, Vianna LAC. Violence against women and care practice in the perception of the health professionals. Texto Contexto Enferm [internet]. 2015 [cited 2016 Jan 10]; 24(1):229-37. Available from: http://www.scielo.br/scielo.php?script=sci arttext\&pid=S0104-07072015000100229\&lng=en\&nr $\mathrm{m}=\mathrm{iso \& t} \operatorname{lng}=\mathrm{en}$

26. Machado JC, Rodrigues VP, Vilela, ABA, Simões AV, Morais RLGL, Rocha EN. Violência intrafamiliar e as estratégias de atuação da equipe de Saúde da Família. Saude Soc. 2014 Jul-Set; 23(3):828-40. 